\title{
Expanding Marketing Principles For The Sale Of Higher Education
}

Denis Rudd, Robert Morris University

Richard Mills, Robert Morris University

\begin{abstract}
This paper will develop and explain a conceptual framework for the use of business industry marketing techniques within the higher educational spectrum. This framework will demonstrate how sound marketing management can help higher education increase its effectiveness and improve student interest, as well as encourage the development of managerial skills that will lead to better operational efficiency. The material will be presented in a detailed, specific, and practical manner that can be utilized by educational administrators. There are many benefits in the utilization of the marketing concept for higher education. Marketing can lead to a better understanding of your customer (student), a more efficient use of money geared specifically towards your target market, a better understanding of where your college or university stands relative to your competitors. Marketing can also help create a more effective use of your human resources and an increased awareness of marketing trends. Marketing, specifically targeted towards the student using the nine $p$ 's and taking into account the differences between marketing for higher education and marketing for products, may result in improved student interest towards the marketed university or college, which may result in higher enrollment
\end{abstract}

Keywords: package, partnership, programming, positioning, people

\section{INTRODUCTION}

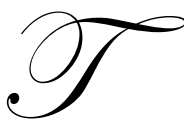

his paper will develop and explain a conceptual framework for the use of business industry marketing techniques within the higher educational spectrum. This framework will demonstrate how sound marketing management can help higher education increase its effectiveness and improve student interest, as well as encourage the development of managerial skills that will lead to better operational efficiency.

\section{THE MARKET MIX (FOUR P'S)}

The marketing concept originated with the four p's (market mix), product, price, place, and promotion. The uniqueness of marketing for higher education requires additional components beyond the market mix. Marketing for higher education is not the same as marketing for a McDonalds' or Nike. Nike uses product marketing whereas education is essentially a service. The additional components that must be added to the marketing mix to address service needs are packaging, partnership, programming, positioning, and people (Economic Planning Group of Canada, 1990). Each of the additional five p's adds further dimension to the market mix for higher education. In marketing for higher education, promotion may have the central role in the marketing mix. This includes the selling and advertising that really help market the company almost more than any other of the p's.

There are two models that will be investigated, that follow the traditional marketing mix. The first model is a general marketing model and it includes the buyer or target market in the center circle around which everything else in the model is situated. Surrounding the buyer are product, price, place and promotion. Surrounding the marketing mix components are all of the outside forces that act on the market mix. This model has traditionally been utilized for product marketing. The model was taken from William Pride's Marketing Basic Concepts and Decisions (3). 


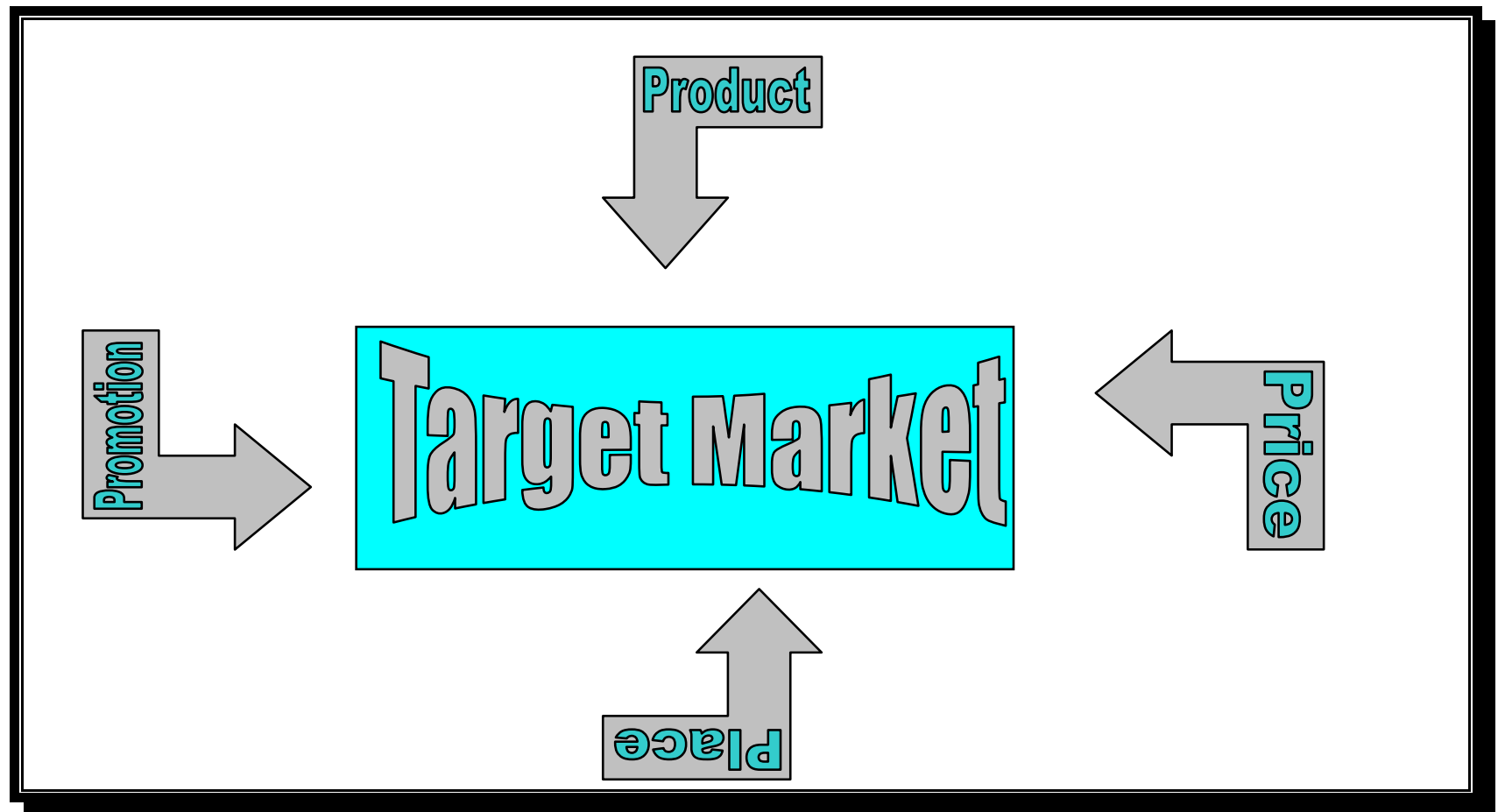

MODEL 2

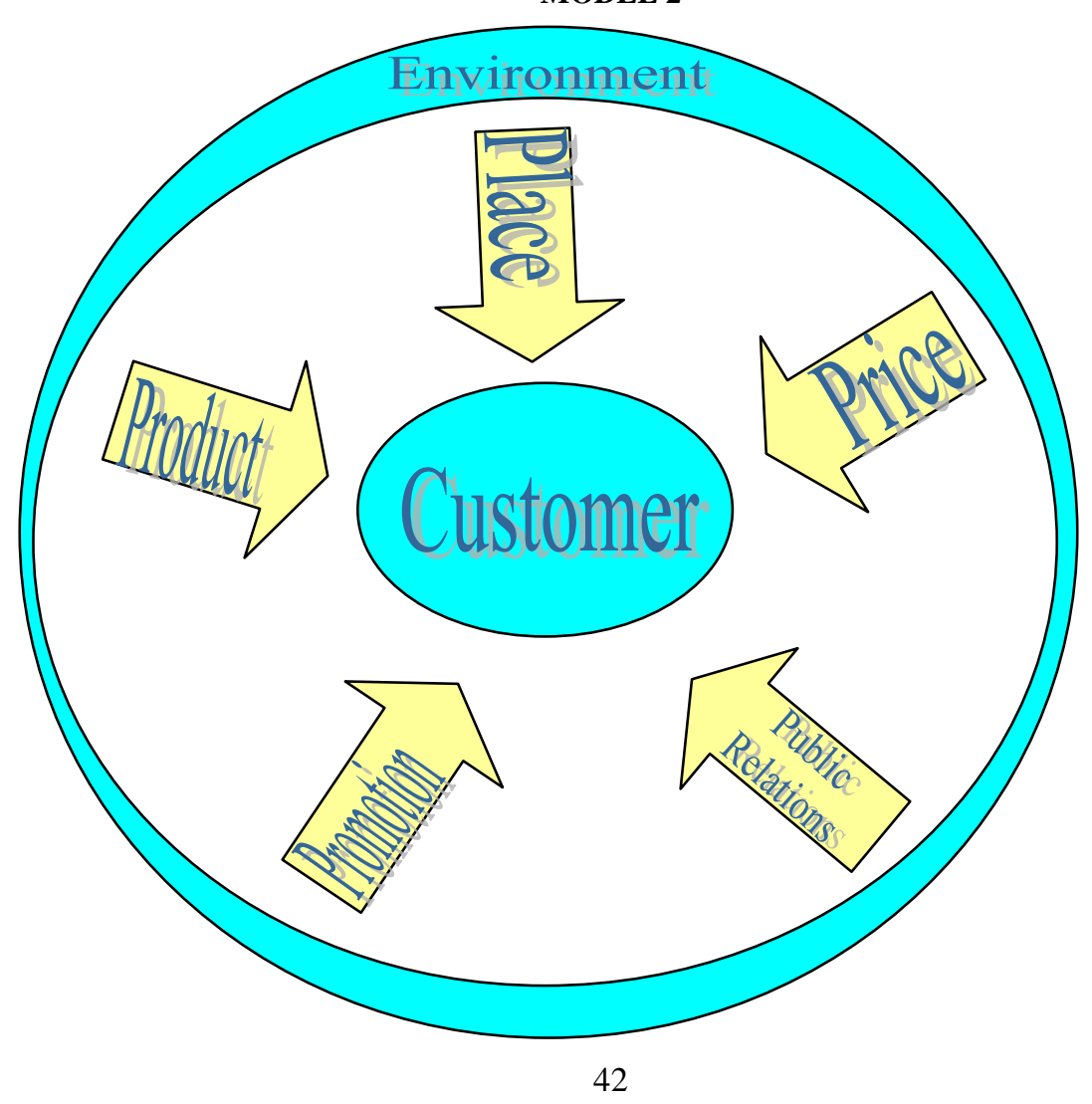


The second model is taken from Bernard Mullin's Sport Management (7) and is specifically directed at the sporting industry. The core benefits are in the center of the model, around which everything else in the model is directed. This particular mix contains product, price, place, promotion and adds a fifth element; public relations. The market mix has been changed to suit various industry needs, but each mix always contains the primary four.

\section{SERVICES VS. PRODUCTS}

Many aspects of the nine p's are similar for all service-oriented businesses; however, marketing for higher education has several unique features:

1. The service offered is intangible rather than tangible (knowledge vs. a new car). Unlike a pair of new shoes the education received through a university or college cannot be touched, felt, or held (Brooks et al., 28).

2. The service offered is inseparable from its product. The service is produced and consumed at the same time (Brooks et al., 1993 p.29).

3. Students make their choices based on a complex mix of motivations. There is a large amount of irrationality involved in the choice of a university or college (Brooks et al., 27).

Today decisions to attend, donate, participate, and study are made by people who often base their decisions on intangible factors. Some schools are discovering the values of marketing their offerings in the most nontechnical ways possible. As part of their approaches they downplay all the internal technical factors that make up this complex business called higher education. Rather than defining their offerings from a specifications point of view, as if higher education were sets of mechanical processes and procedures they are defining the emotional aspect of their services (D.Topor, Online).

4. There is a certain amount of heterogeneity when marketing for universities or colleges. Each time a service is provided it is different (Brooks et al., p.33). Every student in a classroom of forty, will walk away from that class with a different experience.

5. The services that a university or college offers cannot be inventoried therefore they are perishable. This is very different from product-oriented businesses. Automobiles that are unsold can be sold the next day. If a university has five hundred seats available for incoming freshman and only 200 are "sold" it is not possible to sell those same seats a year later, they are gone forever (Brooks et al., 30).

\section{WHY MARKET HIGHER EDUCATION?}

Declining student attendance following the boom of the late 1960's caused many universities and colleges to worry about their financial stability and their ability to stay afloat (Brooks et al, 27). According to George Keller author of The Management Revolution in American Higher Education during the 1970's a revolution in higher education occurred:

America's 3,100 colleges and universities are living through a revolution. It is as profound a change as that which crushed the early nineteenth century world of the tiny religious colleges and created the new era of universities, state land-grand colleges, graduate schools, co-education, research, deans, and postgraduate education for the professional classes at the turn of the century. And it is a shift that is causing unprecedented dismay, confusion, and hand wringing in higher education circles today. Two frequently cited causes of this change are the worsening financial conditions at universities and "Birth Death" of the 1960's and 1970's, which pushed into motion a deep, sustained decline in the number of traditional students availability for college, the first such decline in American educational history (Keller, iii).

Colleges and universities turned to marketing and hope that by marketing their service, they would gain more student attendance. Several other factors have also persuaded colleges and universities to turn to marketing. There is a great deal of competition between institutions of higher education. Within urban areas there are often ten or fifteen institutions of higher learning. With such a bounty to select from how does a student choose among them? Universities hoped to help the students make that choice in their favor by effectively marketing their institution 
(Chen et al, 3). Many universities would also like the opportunity to select from among the students they feel would best suit their institution. With a declining student population this is impossible since almost every student who applies must be accepted simply to keep the university afloat. Marketing allows these institutions to choose from a surplus of students (Chen et al, 3 ).

According to a survey, which was completed by 115 college and university deans and conducted by Raymond E. Taylor et al., "Marketing higher education is a valid operational concept for higher education" In previous years marketing was often considered a dirty word in the educational forum. Recent changes in the available target market have begun to force focused attention on marketing issues in many colleges and universities.

\section{CONCEPTUAL FRAMEWORK}

In constructing a conceptual framework for higher educational marketing, the traditional market mix was included as well as five additional components that particularly suit marketing in higher education. In the center of the circle is the target market. Each of the 9 P's is aimed at the target market. Although many of these components work together it is essential that all nine components be utilized to properly "mix" your marketing plan. The 9 P's are separated by dotted line indicating the maneuverability of these components. They can move freely throughout the circle in any particular order so long as they remain consistently aimed at the target market. The Marketing Model for Higher Education is presented on the following page as Model 3.

\section{MODEL 3}

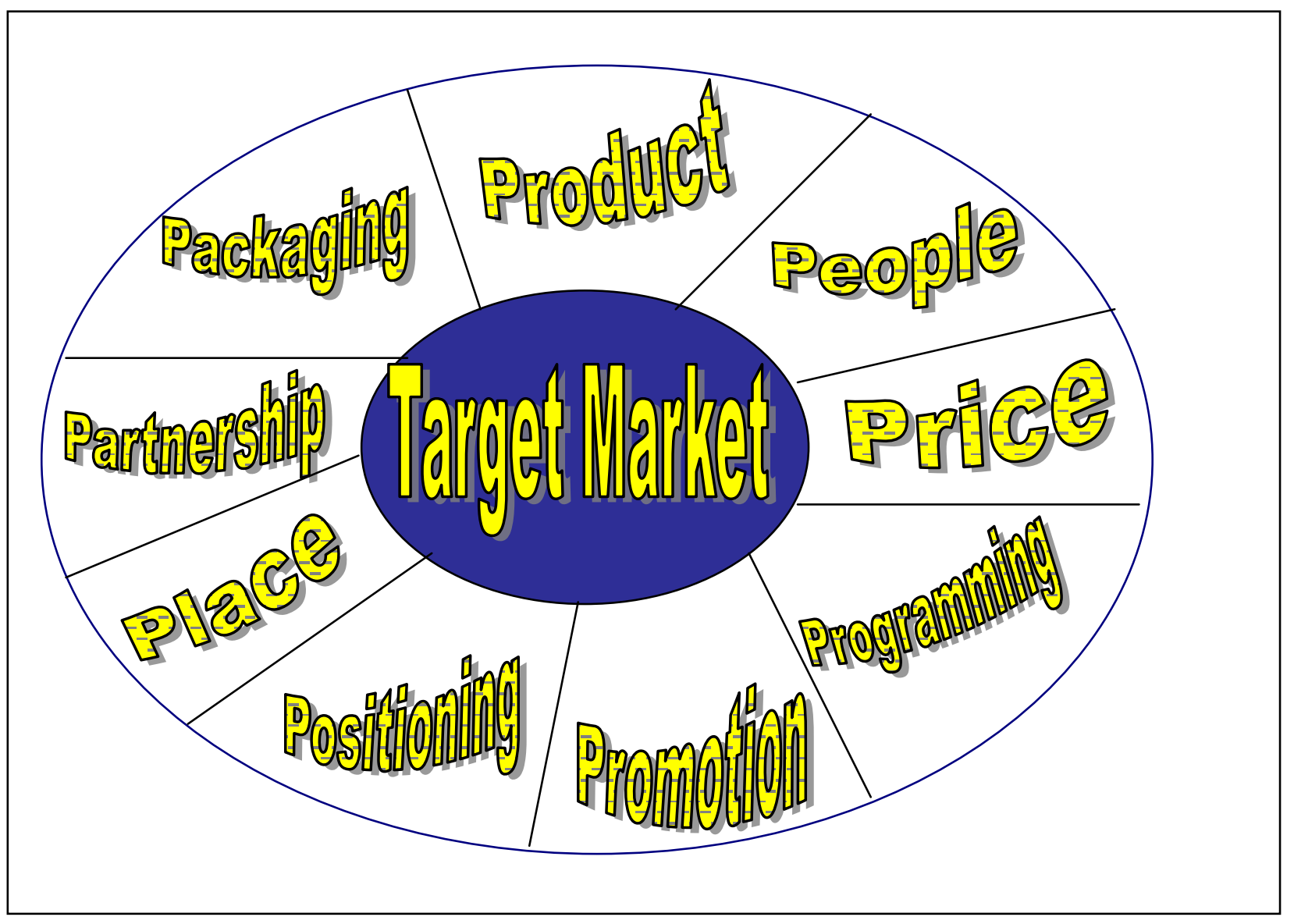




\section{PRODUCT}

The first item of the marketing mix is the product. The product is the full range of activities, facilities, experiences and services provided by a university. This would include food service facilities, sports facilities, dorms, classrooms, teachers, etc. When considering their product in a marketing plan a university must make sure that they include any demand-generators that might enhance their product from a customer's (student's) point of view. These demand-generators might include the university's location, history, culture, or recreational facilities near the university; all of those attributes that would draw a student to your university and are not contained within the universities grounds (Economic Planning Group of Canada, 14).

UCLA is a great example of an exceptional product. This university enrolls 25,432 undergraduates and 11,179 graduates. It is located in Westwood Village in Los Angeles, which is located about five miles from the Pacific Ocean. There are several top notch fitness centers and recreational facilities around UCLA. There are a number of movie theaters and the Westwood area is a great night life area. This location makes this university a prime location and the closeness to a beach can be a huge attraction to a prospective student (About UCLA, 2007).

This university has great tradition. Some of their traditions can be traced back to the early 1920's. Their mascot, a bruin, has been in existence since 1961. With their location being so close to other universities, they have great rivalry traditions. The University of Southern California is their main football rival. This rivalry is a main attraction every year and gets the students involved in an old fashion game. Traditions can help the image of the school (About UCLA, 2007).

The campus life for UCLA is top rated. They have nine different restaurants and cafes for students to eat at. The variety ranges from sandwich bars to pizza places to Mexican specialties. The living arrangements at UCLA is very convenient and is also a strong point for the university (About UCLA, 2007).

Most importantly the academic quality of education at UCLA is well impeccable. They offer 118 undergraduate degree programs and 200 graduate programs. Their library ranks among the top ten in the United States and has 8 million volumes (About UCLA, 2007). The academics itself for this university can attract the students but it is often felt that these other benefits of the university help drive the product and attract potential students.

\section{PEOPLE}

The people component of the higher educational marketing mix refers to the employees in the university or college. It is often that employees can be excellent marketing tools that cost the university or college nothing extra (Brooks et al., 33). One example of employee marketing can be found at Niagara University. Niagara University has an innovative program that utilizes professors in its hospitality department. Professors visit eleven urban schools in Buffalo and Niagara Falls. They demonstrate various aspects of the hospitality industry for kindergarten through twelfth grade students at these schools. Through this program they have attracted over twenty-five students to the Hospitality Program in the past three years. The program is run on a volunteer basis by professors who want to participate.

Many universities and colleges have out-reached programs similar to Niagara University's. The University of Southern California also has a similar program set up. They have twenty organizations they reach out to that helps younger prospects see what the school is about. This can help for the immediate future or even the long term future of the College or the University. Two of their main partners are LAUSD Police Department and the Los Angeles Unified School District (The Power of Partnership, 2007). They often result in an effective and essentially cost-free marketing technique.

Another way to market people is to have the employees of the college or university's accomplishments be known. Florida State University makes it known how qualified their professors are. They have a program set up called "Pathway to Excellence." Because of this program alone, they have hired 200 facility members who are 
national and international leaders in their field. This is a good marketing tool to know that new professors are added regularly and are extremely qualified (Pathways of Excellence, 2007).

\section{PRICE}

Price is the cost that students are asked to pay to complete a course or a degree. The price is an important component of the marketing mix. Overpricing your service sometimes results in a drop in the student population (Economic Planning Group of Canada, 16). For example, community colleges are typically priced at a lower cost than the universities and colleges that surround them. If a community college were to price itself at the same level or beyond that of the local colleges, students would tend to seek out a lower priced community college. When a college or university decides on its price several methods can be applied.

A college may choose to go into direct competition with the colleges around them, offering similar facilities, courses, and of course pricing. This method is generally used for short-term pricing or when a university or college is just opening (Economic Planning Group of Canada, 93). Using this method does have disadvantages; one of these includes the difference in quality or service that might exist between competing colleges. Even though attempts are made to ensure that the services are similar, differences do occur.

Another method of pricing that universities often use is sometimes called the "Exclusive Method" (Economic Planning Group of Canada, 94). Colleges and universities that have an edge on the competition use this. Sometimes this may mean that their facilities or reputation is better than their competitors. Therefore the college charges far more than the education is actually worth. Examples of colleges that employ this method might include Bennington College and St. Lawrence University.

Pricing is often the first marketing challenge that universities face. Accurately calculating what price the target market will endure ensures an adequate pool of students to draw upon.

\section{PROGRAMMING}

Programming is any special events or activities that expand on the service you are offering (Economic Planning Group of Canada). One example of programming in universities is the recent explosion of Saturday degrees offered in area universities and colleges. These have been designed to attract the non-traditional student and leave large amounts of time free to pursue career goals or family life. This programming technique draws students, who might not ordinarily be able to take the time off to pursue a degree full-time.

On-line classes and degrees are quickly becoming desirable for working individuals or individuals with families. At Arizona State University, they now offer on-line degrees. They offer Bachelor's Degrees in Interdisciplinary Studies and Liberal Studies (Online Programs, 2007). The graduate programs include:

\footnotetext{
- $\quad$ W.P. Carey School of Business Online MBA Program

- $\quad$ Ira A. Fulton School of Engineering Online Degree Programs

- $\quad$ Online Master of Science Degree in Technology

- $\quad$ Online Master of Science Degree in Graphic Information Technology

- $\quad$ Master of Nursing Healthcare Innovation

- $\quad$ Master of Advance Study in Geographic Education
}

This type of education at Arizona State University is the same high-quality, accredited education delivered in traditional programs. The advantage enjoyed in one of their online degree programs is the convenience of studying online, anytime or anywhere. There is a wide variety of online resources and tutoring (Online Programs, 2007). It is becoming very popular for non-traditional students and Arizona State University is ahead of many other universities in having this offered. 


\section{PROMOTION}

Promotion consists of the range of activities that simulate interest in a service (Economic Planning Group of Canada, 16). Promotion can very well have the central role in the marketing to higher education. Promotions can enhance name recognition and provide exposure for the college or university. It includes communication, selling, advertising, recruitment, and sales management.

Two promotional strategies commonly used in advertising and promotional activities are the push strategy and the pull strategy. The push strategy concentrates on the intermediaries to push the service to the customer. Primary advertising would be though personal selling directed at school counselors and teachers. Network marketing, which is described as the use of high school counselors, teachers, alumni, parents, and others to help create an institutional image to convert prospective students to applicants, plays a big role in the schools success at promoting. High School counselors are responsible for assisting their students find information out about certain colleges and make recommendations. Also current students are often a good marketing tool because they are close in age with the current students and tell them exactly what to expect. Other push strategies include advertising through television, radio, bill boarding, and brochures (Hayes, 2002).

In the pull strategy the university or college directs its efforts directly on the student to attend the college, which will pull the service through the intermediaries. This technique primarily uses advertising and is consumer promotion (Kotler, 508). Successfully using promotional techniques generally means that the university has an idea of its position in the market and has established prices. Telemarketing can be an effective way to personalize the recruitment process and get responses quick. Direct mail strategies are used to send out admissions material and onand off-campus programs. This can be effective but at times only leads to one-way communication (Hayes, 2002).

Off-campus visits to high schools can be very effective. It provides an opportunity to make what the school has to offer more tangible. The primary goal of the campus visit is to give the student a much better aspect of what the school is about culturally and socially. Colleges or Universities also recruit on campus. They have Preview/Open House Days to interested students. A college or university has several days through out the year where the potential applicants can come and hear about the school and their programs. Promotions are a very essential part in the marketing of a university (Hayes, 2002).

The model below, Model 4, is the Recruitment Cycle. The cycle shows the three stages before the student registers. This is a great model to show universities or colleges how to go about obtaining a potential student (Hayes, 2002).

Model 4

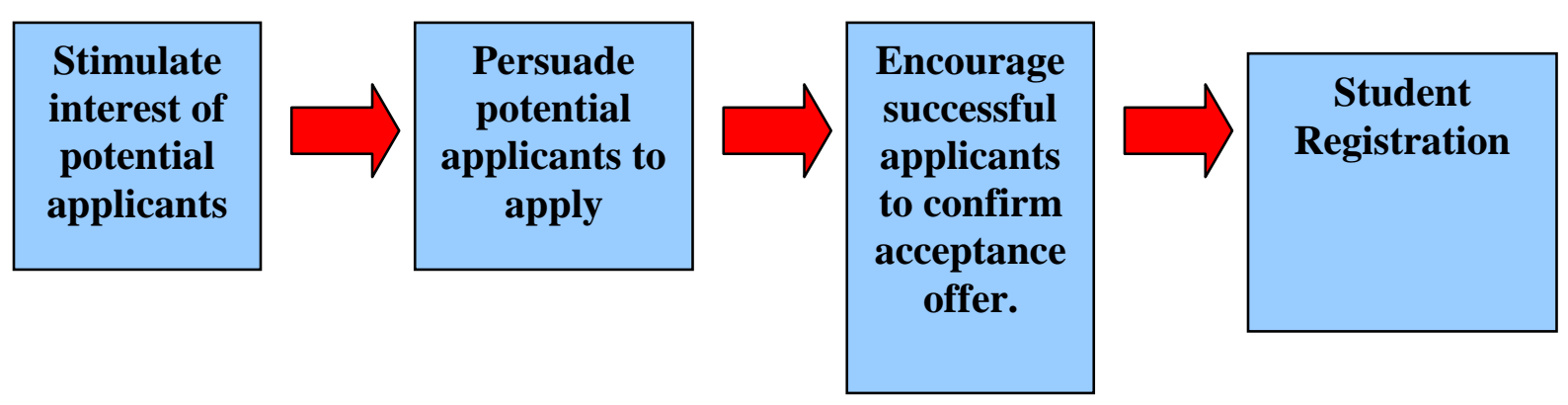

\section{POSITIONING}

Positioning is the market-niche a college holds (Lewis, 260). Richard C. Lewis has created a positioning checklist that is helpful when deciding on a positioning strategy: 
1. Does it say who you are and what you stand for? Does it create a mental picture?

2. Does it set you apart and show how you are different?

3. Does it preempt a benefit niche and capitalize on an advantage?

4. Does it turn any liability into an asset?

5. Does it have benefits fro the target market you are trying to reach?

6. Does it provide tangible evidence or clues?

7. Does it feature the one or two things that your target market wants most?

8. Is it consistent with strategy-for instance, does it expand or exchange usage patterns? Create new awareness? Project the right image?

9. Does it have credibility?

10. Doe it make a promise you can keep? (287)

Creating an effective positioning strategy will facilitate better understanding between the target market and the college. When a student knows exactly what they are going to be receiving out of a college experience, they are more likely to stay in college and be satisfied with their college experience. According to Leister positioning is a very important component in the marketing mix: a competitive marketing strategy involving the creation of a special place for one's product in the minds of the customer relative to other products in the same market. This involved: (1) an assessment of the current product position, (2) a determination of the dimensions underlying the position of the product, (3) selection of a new product position based on new dimensions (380).

Duke University clearly defines where they stand in academics and their vision towards the future. They have made just limited changes to their mission statement that was written in 1994, which shows this school has a great understanding of the position of the university. Their mission statement reads:

"The mission of Duke University is to provide a superior liberal education to undergraduate students, attending not only to their intellectual growth but also to their development as adults committed to high ethical standards and full participation as leaders in their communities; to prepare future members of the learned professions for lives of skilled and ethical service by providing excellent graduate and professional education; to advance the frontiers of knowledge and contribute boldly to the international community of scholarship; to promote an intellectual environment built on a commitment to free and open inquiry; to help those who suffer, cure disease, and promote health, through sophisticated medical research and thoughtful patient care; to provide wide ranging educational opportunities, on and beyond our campuses, for traditional students, active professionals and life-long learners using the power of information technologies; and to promote a deep appreciation for the range of human difference and potential, a sense of the obligations and rewards of citizenship, and a commitment to learning, freedom and truth.

"By pursuing these objectives with vision and integrity, Duke University seeks to engage the mind, elevate the spirit, and stimulate the best effort of all who are associated with the University; to contribute in diverse ways to the local community, the state, the nation and the world; and to attain and maintain a place of real leadership in all that we do."

Along with this excellent mission statement, Duke has recently formed a strategic plan called "Making a Difference." They feel that "Making a Difference" is what their actions will do to others around the world. This plan looks away from the traditional model for universities. This new model really emphasizes specialized research and dedication. The mission statement and the recently developed strategic plan show how Duke positions themselves to current and potential students.

\section{PLACE}

The place component of the marketing mix for higher education refers to when, where, and by whom a service is offered for sale (Economic Planning Group of Canada). In applying this component to universities and colleges, when, alludes to the time of year or particular days of the year when marketing is intense. This is often during certain times during the fall and spring to take advantage of students in high schools that make their college choices during this time period. Where, refers to the place at which the service is offered for sale, and by whom 
refers to the person doing the selling. Universities have a public relations department that handles marketing and whom may also include employees and alumni.

Since 1972, the National College Fairs program has helped students in fulfilling their higher education aspirations. It is free to the public. It allows students to interact with admission representatives from a wide range of institutions to discuss a variety of topics. More than 1,600 institutions exhibit with National College Fairs annually.

Many universities go to other states in hopes to recruit out of town students. The out of state students often pay a higher tuition than in state students, so it is harder to attract these potential students. So as you can see, these fairs are important. An example of this would be how several schools from New York, West Virginia, Ohio, and Virginia often travel to Pennsylvania to attract as many students as possible. They go to these college fairs usually in October and March because these are the key times to attract potential students. Place can really help drive a schools enrollment and the type of students they can acquire.

\section{PARTNERSHIP}

A partnership consists of two or more businesses that offer complementary services and pool their resources and marketing efforts (Economic Planning Group of Canada, 16). College and universities have articulation agreements between themselves and local community colleges. These articulation agreements consist of entire courses of study being accepted at the college for full credit. This means that the student can transfer in at least 60 credits compared to the 30 credits that are usually allowed at most universities. Community colleges and universities often advertise these articulation agreements in a combined effort making the partnership complete. These articulation agreements are sometimes referred to as $2+2$ programs, meaning 2 years at a community college and 2 years at a university.

An example of this type of partnership is an agreement with Ohio State University and Columbus State Community College. These two schools have been linked together since 1987. Under this agreement, like stated above, a student can attend Columbus State Community College then transfer directly to Ohio State University. This agreement provides students with the flexibility to transfer after a course, a quarter or two, or a year or two of community college study. This partnership makes it very attractive for students who are not certain of the direction they want to go post high school graduation. An admissions guarantee assures admission to Ohio State for all students who have earned the Associate of Arts (AA) or Associates of Science (AS). These students can compete on an equal basis with current Ohio State students for access to selective programs such as business and engineering.

A dual degree provision allows transfer students from Columbus State the opportunity to use their Ohio State credits to earn both a bachelors degree and a Columbus State associate degree without returning to Columbus State. This also provides associate degree completion opportunities for the Columbus State transfer student who finds it necessary to interrupt their university enrollment. "It is a partnership which broadens opportunities for all central Ohio students by enabling a smooth transition from Columbus State to Ohio State. The agreement should increase degree completion rates and remove some student anxieties about the timing of their transfer. This is the first agreement of such in Ohio and many hope that other community colleges and Universities join in such partnership. In the first ten years of the agreement, 2,942 students have transferred to Ohio State from Columbus State College.

\section{PACKAGING}

Packaging is similar to partnership, however; all of the services can be purchased for a single price. Many universities offer internships to their students, these internships are part of the program and generally cost nothing extra. They are included in the price of the course work. When combined with a partnership (articulation agreement) this creates a package.

The University of Pittsburgh has programs set up that are called "Co-Ops". These programs allow students to work as an intern for a semester and then go back to school. This cycle repeats and a student can spend his college 
career bouncing back from real life work and general college studies. They are very successful and allow a student to get valuable experience to use on their resume. The National Security Agency, NSA, is a big partner with Pitt and often use interns from this university every other semester

\section{CONCLUSION}

A college or university needs to understand three basic tenets of marketing. The first tenet is that marketing is necessary no matter which stage of development the institution may be . Whether it is to inform, reinforce, or remind the prospective student marketing is necessary. The second tenet is that marketing should be consistent and ongoing. There are always consumers who have not heard or do not remember hearing about your institution. The third tenet is that marketing is not a cure-all. If a college does not offer students what they want and need at a reasonable value, marketing can do little to improve the student population.

The conceptual framework developed in this paper is theoretical in nature. The use of the $9 \mathrm{P}$ 's in a marketing mix designed specifically for higher education will allow administrators to see the differences between product oriented marketing and service oriented marketing. This framework will allow administrators to create a marketing plan that contains the components necessary for successful marketing for their university or college.

Educational marketing is unique because of the intangibleness of the product. It can't be stored and it is a

blend of many independent components and intermediaries play a critical role. Marketing for higher education must; therefore, rely on a more streamlined market mix for its service.

\section{REFERENCES}

1. About UCLA. 2007. <www.ucla.edu/about.html>.

2. Blomstrom, R. (1983). Strategic Marketing Planning in the Hospitality Industry. Michigan, Educational Institute of the American Hotel and Motel Association.

3. Brooks, L. \& Hammons, J. (1993). Has Higher Education Been Using the Wrong Marketing Approach? Journal of Marketing for Higher Education: 27-47.

4. Brooks, L. \& Hammons, J. (1993). Has Higher Education Been Using the Wrong Marketing Approach? Journal of Marketing for Higher Education: 27-47.

5. Brooks, L. \& Hammons, J. (1993). Has Higher Education Been Using the Wrong Marketing Approach? Journal of Marketing for Higher Education: 27-47.

6. Chen, H. Effective Marketing Strategies Flow From Sounds Segmentation Data. 1998. <(ERIC Document Number 318386>.

7. College Fairs. 2007. <http://www.nacacnet.org/MemberPortal/Events/CollegeFairs/>.

8. Economic Planning Group . Tourism is Your Business: Marketing Management. Canada, Maclean Hunter, 1990.

9. Goldgehn, L. (1990). Are U.S. Colleges and Universities Applying Marketing Techniques Properly and Within the Context of an Overall Marketing Plan?. Journal of Marketing for Higher Education, 3: 5-27.

10. Hayes, L. An Analysis Of Marketing Strategies For The Recruitment Of Students Into Baccalaureate Nursing Programs In Ontario. Diss. University of Toronto, 2002. Abstract.

11. Hayes, T. (1991). New Strategies in Higher Education Marketing. Binghamton: Haworth.

12. Keller, G. (1991). Management Revolution in American Higher Education. Baltimore John Hopkins University Press

13. Kotler, P. (1996). Marketing for Hospitality and Tourism. New Jersey: Prentice Hall.

14. Leister, D. (1991). Identifying Institutional Clientele. Journal of Higher Education 2 46: 381-399.

15. Lewis, R. \& Chambers, R. (1989). Marketing Leadership in Hospitality: Foundations and Practices. New York: Van Nostrand Reinhold.

16. Markin, R. (1982). Marketing: Strategy and Management. New York: John Wiley and Sons.

17. Mullin, B. (1993). Sport Marketing. United States: Prentice Hall.

18. Ohio State Renews, Enhances Agreement With Columbus State. 1997. <www.osu.edu/osu/newsrel/Archive/97-01-22_Articulation_with_Columbus_State_Enhanced>. 
19. Pathways of Excellence. 2007. 〈http://pathways.fsu.edu/>.

20. Pride, W. \& Farrell, O. (1987). Marketing: Basic Concepts and Decisions. New Jersey: Houghton Mifflin Company.

21. Rubino, D. (1988). A Study of Marketing as Practiced by Selected Independent Colleges and Universities. Pittsburgh: David Alan Rubino.

22. Ryans, C. \& Shanklin, W. (1986). Strategic Planning, Marketing and Public Relations, and Fund-Raising in Higher Education: Perspectives, Readings, and Annotated Bibliography. New Jersey: Scarecrow.

23. Stanton, W. (1971). Fundamentals of Marketing. New York: McGraw Hill.

24. Taylor, R. \& Darling, J. (1991). Perceptions Toward Marketing Higher Education: Do Academic Disciplines Make a Difference? Journal of Marketing for Higher Education, 4: 17-37.

25. The Power of Partnership: USC and Its Community. 2007. <www.usc.edu/community/>.

26. Topor, R. (1996). Nurturing Marketing. Marketing Higher Education. <www.marketing.com/news/nutur.html.>.

27. Topor, R. (1996). Assessing Marketing: a New Concept for Many People. Marketing Higher Education. Marketing Higher Education. <www.marketing.com/news/assess.html>.

28. Topor, R. (1996). Challenge to Higher Education Presidents... Needing Marketing Isn't Enough. Marketing Higher Education. <www.marketing.com/news/presiden.html >.

29. Topor, R. (1996). Organizing an Institution of Higher Education for Effective Marketing: a New Paradigm. Marketing Higher Education. <www.marketing.com/news/organize.html>.

30. Topor, R. (1996). Ten Criteria for Mission Statement Evaluation: How to Market Your School, College or University. Marketing Higher Education. <www.marketing.com/news/mission.html>. 
NOTES 